\title{
Exogenous spermidine-induced changes at physiological and biochemical parameters levels in tomato seedling grown in saline-alkaline condition
}

\author{
Yi Zhang ${ }^{1,2,3+}$, Li Zhang ${ }^{1,3+}$ and Xiao-Hui Hu, $u^{1,3^{*}}$
}

\begin{abstract}
Background: Tomato is one of the most popular vegetables, and middle tolerance for salt stress. Spermidine (Spd) has an important role in plant defense mechanisms against abiotic stress; however, relatively few data are available regarding Spd in responses of tomato to saline-alkaline stress. The effect of $0.25 \mathrm{mmol} / \mathrm{L} \mathrm{Spd}$ on some physiological parameters of two tomato cultivars grown in $75 \mathrm{mmol} / \mathrm{L}$ saline-alkaline solutions were studied. Two cultivars are $\mathrm{CV}$. Jinpeng chaoguan which is a highly salt-tolerant ecotype and cv. Zhongza No. 9 which is more salt-sensitive ecotype.

Results: Saline-alkaline stress upset nitrogen metabolism, induced the antioxidant enzyme activities, and accumulated much more reactive oxygen species (ROS) and osmoregulation substances in two tomato cultivars leaves. Under saline-alkaline stress condition, Spd-treated seedlings accumulated more osmoregulation substances and had greater activities of antioxidative enzymes. Exogenous Spd counteracted the stress-induced increase of contents of malondialdehyde and ammonium, glutamate dehydrogenase activity, and decreased in nitrate, nitrate reductase, nitrite reductase, glutamine synthetase, glutamate synthase, glutamate oxaloacetate transaminase, and glutamate pyruvate transaminase activities. Additionally, the effect of Spd was more significantly in salt-sensitive cultivar 'Zhongza No. 9'.
\end{abstract}

Conclusions: Overall, exogenous spermidine can attenuate negative effects of saline-alkaline stress on tomato seedlings which effects may depend on the plant species, and even cultivars.

Keywords: Tomato; Saline-alkaline stress; Spermidine; Nitrogen metabolism; Antioxidant enzyme; Osmoregulation substance

\section{Background}

Saline-alkaline condition imposes a major abiotic stress on crops and represents an important limiting factor of productivity. It has been estimated that one-third of the world's irrigated land is unsuitable for crops due to its saline condition (Frommer et al. 1999; Wasti et al. 2012). Plant responses to mixed salt and alkali stress are more

\footnotetext{
*Correspondence: hxh1977@163.com

${ }^{\dagger}$ Equal contributors

${ }^{1}$ College of Horticulture, Northwest Agricultural \& Forest University, Yangling 712100, China

${ }^{3}$ Key Laboratory of Protected Horticultural Engineering in Northwest, Ministry of Agriculture, Shaanxi Yangling, 712100, China

Full list of author information is available at the end of the article
}

complex than their responses to either simple salt or alkali stress (Shi and Sheng 2005; Yang et al. 2007) and there have been few studies of complex neutral and alkaline salt stress. In general, plant metabolism is altered and a range of defense mechanisms are activated in response to abiotic stress, presumably to compensate for the changed environmental conditions (Wasti et al. 2012). Stress could induce excessive generation of reactive oxygen species (ROS) including superoxide anion $\left(\mathrm{O}_{2}{ }^{-}\right)$, hydrogen peroxide $\left(\mathrm{H}_{2} \mathrm{O}_{2}\right)$ and hydroxyl radical $\left(\mathrm{HO}^{-}\right)$, which could cause deterioration of membrane lipids, proteins and nucleic acids, leading to increased membrane leakage of solutes (Shehab et al. 2010; Huang et al. 2013). One stress-defense 
mechanism in plants is the accumulation of compatible osmolytes (Shahba et al. 2010), which can also be induced or enhanced by the application of chemicals to the plant (Rhodes et al. 1999).

Polyamines are low-molecular-weight aliphatic amines with important functions in growth, cell division, DNA replication, and protein synthesis (Roychoudhury et al. 2011). Spermidine (Spd), spermine, and putrescine are major polyamines in plants that act as second messengers, mediating responses to various environmental stressors. These stressors include osmotic stress, changes in salinity, drought conditions, and exposure to ozone, heavy metals, and ultraviolet light (Groppa and Benavides 2008). Compared with other type of polyamine, Spd could more effectively alleviate the adverse impacts of salinityalkalinity (Hu et al., 2012).

Despite research efforts, little is known about the physiological functions of exogenous $\mathrm{Spd}$ in response to salt-alkali mixed stress. The objective of this work was to determine effects of Spd under saline-alkaline conditions in two tomato cultivars with different salinity tolerance. The response in terms of nitrogen metabolism, antioxidant enzyme activities, contents of ROS and osmoregulation substances were evaluated in order to evaluate the role of Spd in promoting tomato plants tolerance to saline-alkaline stress.

\section{Methods}

\section{Plant materials and treatments}

Two tomato (Solanum lycopersicum) cultivars were used in the study. cv. Jinpeng chaoguan is a highly salttolerant ecotype, while cv. Zhongza No. 9 is more saltsensitive ecotype (Hu et al. 2012). Tomato seeds were surface-sterilized with $4 \%(\mathrm{v} / \mathrm{v})$ sodium hypochlorite, rinsed with distilled water, soaked in distilled water for $6 \mathrm{~h}$ at $26^{\circ} \mathrm{C}$, and transferred to sterile moist Whatman No. 1 filter paper which moistened with distilled water in Petri plates. The plates were maintained in the dark at $26^{\circ} \mathrm{C}$ for germination. Uniformly germinated seeds were selected and cultivated in polystyrene trays filled with complex organic substrates and placed in a greenhouse with an average temperature of $26-30^{\circ} \mathrm{C}$ during the day and $16-18^{\circ} \mathrm{C}$ at night, a 16 -h light $(600-800 \mu \mathrm{mol}$. photons $/ \mathrm{m}^{2} \cdot \mathrm{s}$ ) followed by an 8 -h dark photoperiod, and a $50-90 \%$ relative humidity. When the third leaves were fully expanded, we transplanted all of the seedlings into rectangular hydroponic containers containing continuously aerated half-strength Hoagland's nutrient solution. When tomato seedlings were at the sixth true leaves stage, the seedlings were treated with the following treatments: (1) control (CK), half-strength Hoagland's nutrient solution cultivation, (b) saline-alkaline treatment, tomato seedlings were exposed to half-strength Hoagland's nutrient solution cultivation contain $75 \mathrm{mmol} / \mathrm{L}$ saline-alkaline solution $\left(\mathrm{NaCl}: \mathrm{Na}_{2} \mathrm{SO}_{4}: \mathrm{NaHCO}_{3}: \mathrm{Na}_{2} \mathrm{CO}_{3}=\right.$ 1:9:9:1), (c) saline-alkaline plus Spd treatment, tomato seedlings were exposed to half-strength Hoagland's nutrient solution cultivation contain $75 \mathrm{mmol} / \mathrm{L}$ saline-alkaline solution and sprayed with $0.25 \mathrm{mmol} / \mathrm{L}$ Spd (SigmaAldrich, St. Louis, MO, USA). The experiment took place in a greenhouse covered totally with polycarbonate sheets and located at the horticultural experimental station of Northwest Agriculture \& Forestry University, China. The experiment design included 3 treatments of each cultivar, totally being 6 treatments with 3 times under the same conditions. Each treatment has 3 containers, and each container includes 12 plants every time. The sixth leaves were harvested 4 days after the treatment for analysis different indexes.

\section{Analyses of $\mathrm{NO}_{3}^{-}-\mathrm{N}$ and $\mathrm{NH}_{4}^{+}-\mathrm{N}$ levels}

Leaf samples were dried at $75^{\circ} \mathrm{C}$ until constant weight was obtained. The dried material $(200 \mathrm{mg}$ ) was ground to a powder and extracted in $10 \mathrm{~mL}$ of distilled water for 2.5 h. Contents of $\mathrm{NO}_{3}^{-}-\mathrm{N}$ and $\mathrm{NH}_{4}^{+}-\mathrm{N}$ were determined according to the method of Cataldo et al. (1975) and Krom (1980), respectively.

\section{Assays of nitrogen metabolism enzymes}

Nitrate reductase (NR), nitrite reductase (NiR), Glutamate dehydrogenase (GDH) and Glutamate synthetase (GOGAT) activities were estimated according to the methods of Gangwar and Singh (2011). Glutamine synthetase (GS) activity was measured using an adaptation of Lillo's method (Lillo 1984). The activities of glutamate oxaloacetate transaminase (GOT) and glutamate pyruvate transaminase (GPT) were measured with the method described by Liang et al. (2011).

\section{Antioxidant enzyme activity, $\mathrm{H}_{2} \mathrm{O}_{2}, \mathrm{O}_{2}{ }^{-}$and malondialdehyde assay}

Superoxide dismutase (SOD) activity was assayed as previously described by Dhindsa et al. (1981). One unit of activity was defined as the amount of enzyme required to inhibit the reduction of nitro blue tetrazolium chloride by $50 \%$ at $560 \mathrm{~nm}$. Peroxidase (POD) activity was assayed as previously described (Kochba et al. 1977). One unit of activity was defined as the amount of enzyme required to increase absorbance by 0.1 absorbance units at an optical density of $470 \mathrm{~nm}$ per min. Catalase (CAT) activity was assayed as described by Dhindsa et al. (1981). One unit of activity was defined as the amount of enzyme required to decrease 0.1 absorbance units at an optical density of $240 \mathrm{~nm}$ per min. Contents of $\mathrm{H}_{2} \mathrm{O}_{2}$ and $\mathrm{O}_{2}^{-}$were detected in leaves as described by Orozco-Cardenas et al. (2001). The content of malondialdehyde (MDA) was measured according to the method of Xu et al. (2008). 


\section{Measurements of proline, soluble sugar, and soluble protein}

The proline content was estimated following the method of Bates et al. (1973). Soluble sugars were estimated by the anthrone reagent method using glucose as the standard (Yemm and Willis 1954). Protein was determined according to the method of Bradford (1976) using bovine serum albumin as a standard.

\section{Statistical analysis}

All data presented are the mean values. All experiments were conducted using three replicates at least. All data were statistically analyzed by the analysis of variance (ANOVA) with SAS software (Version 8.1; SAS Institute, Cary, NC, USA)) using Duncan's multiple range test at the 0.05 level of significance.

\section{Results and discussions}

\section{The effect of Spd on $\mathrm{NO}_{3}^{-}-\mathrm{N}$ and $\mathrm{NH}_{4}^{+}-\mathrm{N}$ content}

Nitrogen, required in great quantities by plants, is an essential macronutrient and involved in the biochemistry of coenzymes, PAs, photosynthetic pigments, secondary metabolites, and so on. Although there are several forms of nitrogen, nitrate $\left(\mathrm{NO}_{3}{ }^{-}\right)$is considered to be the most available form of nitrogen in higher plants (Gajewska and Sklodowska 2009), and it accumulates in vacuoles where it is innocuous. However, $\mathrm{NO}_{3}{ }^{-}$is only a storage form of nitrogen and must be reduced to ammonium $\left(\mathrm{NH}_{4}{ }^{+}\right)$before it can be incorporated into organic compounds. The content of $\mathrm{NO}_{3}^{-}-\mathrm{N}$ and $\mathrm{NH}_{4}{ }^{+}-\mathrm{N}$ in leaves of two tomato cultivars were clearly affected by salinealkaline or saline-alkaline plus Spd (Figure 1). Under salinity-alkalinity stress, $\mathrm{NO}_{3}{ }^{-}-\mathrm{N}$ content in both cultivars leaves significantly decreased and 'Jinpeng chaoguan' was higher $\mathrm{NO}_{3}^{-}-\mathrm{N}$ levels than 'Zhongza No. 9', while $\mathrm{NH}_{4}{ }^{+}-\mathrm{N}$ content in both cultivars leaves significantly increased
$(P<0.05)$, and 'Jinpeng chaoguan' was lower $\mathrm{NH}_{4}{ }^{+}-\mathrm{N}$ levels than 'Zhongza No. 9'. Although the change of the $\mathrm{NO}_{3}{ }^{-}-\mathrm{N}$ and $\mathrm{NH}_{4}{ }^{+}-\mathrm{N}$ contents occurred in both cultivars, the amplitude of change was higher in 'Zhongza No. 9' than in 'Jinpeng chaoguan'. The $\mathrm{NO}_{3}{ }^{-}-\mathrm{N}$ decrease may be attributed to an uptake competition between $\mathrm{NO}_{3}{ }^{-}$and other existing anions such as $\mathrm{Cl}^{-}, \mathrm{SO}_{4}{ }^{2-}$ and $\mathrm{CO}_{3}{ }^{2-}$, which may have unfavorable influences on plasma membrane permeability. The content of $\mathrm{NH}_{4}^{+}-\mathrm{N}$ increased, perhaps from aggravated ion toxicity, imbalance of osmotic regulation, and/or $\mathrm{N}$ metabolic disturbance from the salinityalkalinity stress. While exogenous Spd treatment increased $\mathrm{NO}_{3}{ }^{-}-\mathrm{N}$ content and reduced the $\mathrm{NH}_{4}{ }^{+}-\mathrm{N}$ content in both cultivars leaves compared to that in only stressed leaves. Overall, 'Zhongza No. 9' showed more sensitivity to both salinity-alkalinity stress and exogenous Spd; however, no significant differences in the $\mathrm{NH}_{4}^{+}-\mathrm{N}$ content of 'Jinpeng chaoguan' seedlings grown with exogenous Spd.

\section{The effect of Spd on activities of nitrogen metabolism enzymes}

The process of the transformation of $\mathrm{NO}_{3}{ }^{-}$to $\mathrm{NH}_{4}{ }^{+}$involves the successive enzymes catalysis ( $N R$ and NiR), meanwhile, NR is the rate-limiting enzyme of nitrogen assimilation. Therefore, the activity of NR can be used as an indicator of the extent of plant nitrogen metabolism. Glutamine synthetase (GS), GOGAT and GDH are the main enzymes involved in the conversion of inorganic nitrogen to organic nitrogen and in reducing ammonia toxicity (Dev and Herbert 2002). The GS-GOGAT pathway can convert excess $\mathrm{NH}_{4}^{+}$into glutamic acid under drought and salt stress conditions. Ammonium ions are rapidly incorporated into organic compounds by the action of GS (Masclaux-Daubresse et al. 2006). The activities of the NR, NiR, GOGAT, GS, GDH, GOT, and GPT in all treatments are shown in Figure 2. Salinity-
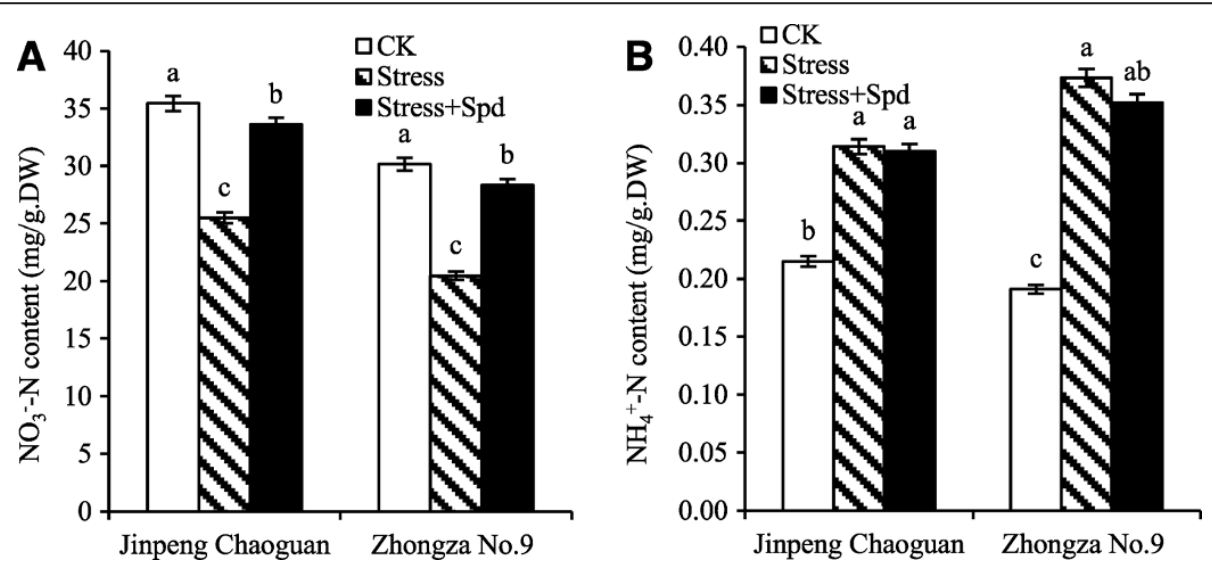

Figure 1 Effects of exogenous Spd on contents of $\mathrm{NO}_{3}{ }^{-}-\mathrm{N}(\mathrm{A})$ and $\mathrm{NH}_{4}{ }^{+}-\mathrm{N}(\mathrm{B})$ in leaves of tomato seedlings under salinity-alkalinity mixed stress (nutrient solution with $75 \mathrm{mmol} / \mathrm{L}$ saline-alkaline solution; $\mathrm{NaCl}: \mathrm{Na}_{2} \mathrm{SO}_{4}: \mathrm{NaHCO}_{3}: \mathrm{Na}_{2} \mathrm{CO}_{3}=1: 9: 9: 1$ ). Data represent means of three replicates. Bars represent the mean $\pm \mathrm{SE}(P<0.05)$ of at least three independent experiments. 

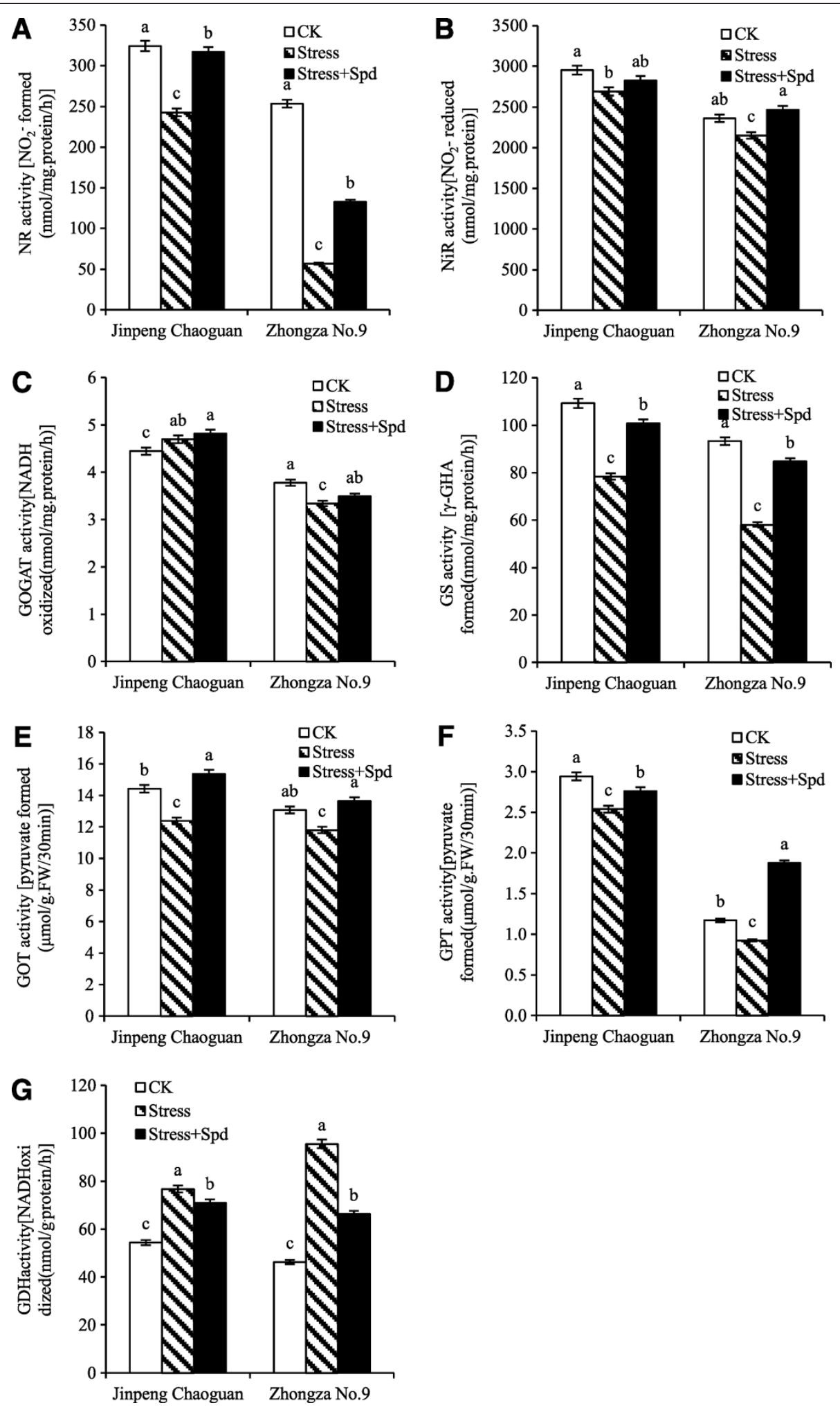

Figure 2 Activities of nitrogen metabolism enzymes in leaves of tomato seedlings grown in nutrient solution or in 75 mM saline-alkaline solution (nutrient solution with $75 \mathrm{mmol} / \mathrm{L}$ saline-alkaline solution; $\mathrm{NaCl}: \mathrm{Na}_{2} \mathrm{SO}_{4}: \mathrm{NaHCO}_{3}: \mathrm{Na}_{2} \mathrm{CO}_{3}=1: 9: 9: 1$ ) with or without $0.25 \mathrm{mmol} / \mathrm{L}$ Spd. Data represent means of three replicates. Bars indicate \pm SE $(P<0.05)$. A delegated NR activity, B delegated NiR activity, $\mathbf{C}$ delegated GOGAT activity, $\mathbf{D}$ delegated GS activity, E delegated GOT activity, $\mathbf{F}$ delegated GPT activity, G delegated GDH activity. Bars represent the mean \pm SE $(P<0.05)$ of at least three independent experiments. 
alkalinity stress caused a reduction in activities of NR, NiR, GS, GOT, GPT and caused an increase in GDH activity of both cultivars. Meanwhile, the amplitude of reduction of NR, GS and GPT activities was higher in 'Zhongza No. 9' than in 'Jingpeng chaoguan', the amplitude of reduction of GOT activity was lower in 'Zhongza No. 9' than in 'Jingpeng chaoguan'. Under salinityalkalinity stress, the GOGAT activity increased in 'Jingpeng chaoguan' and reduced in 'Zhongza No. 9'. In this study, leaves from plants grown under salinealkaline stress had less $\mathrm{NO}_{3}^{-}-\mathrm{N}$ and more $\mathrm{NH}_{4}^{+}-\mathrm{N}$ (Figure 1), accompanied by lower NR and NiR activities (Figure 2A and $\mathrm{B}$ ) than that in leaves from non-stressed plants. Thus, it was suggested that lower levels of $\mathrm{NO}_{3}$ ${ }^{-}-\mathrm{N}$ and reduced NR and NiR activity are early symptoms of salinity-alkalinity stress. The increase in $\mathrm{NH}_{4}$ ${ }^{+}-\mathrm{N}$ under saline-alkaline stress may be attributable to aggravating ion toxicity, imbalance of osmotic regulation, or a stress-induced nitrogen metabolic disturbance. The reduced activities of NR and NiR in stressed plants may have minimized the toxicity of excess $\mathrm{NH}_{4}{ }^{+}$(Wang et al. 2007) by inhibiting the conversion of $\mathrm{NO}_{3}{ }^{-}-\mathrm{N}$ to $\mathrm{NH}_{4}{ }^{+}-\mathrm{N}$ and reducing $\mathrm{NO}_{3}{ }^{-}-\mathrm{N}$ uptake. It also may be that rapid assimilation of $\mathrm{NH}_{4}{ }^{+}$through the GS/GOGAT pathways was stimulated during salt stress. In this study, the results showed that the activities of GOT, GPT, GOGAT and GS were significantly suppressed under only salinealkaline stress comparing with control (Figure 2C,D,E and F). This suggests that during saline-alkaline stress, $\mathrm{NH}_{4}{ }^{+}$competition and ammonia assimilation are mainly via the GDH pathway. In this experiment, saline-alkaline stress induced the activity of GDH (Figure 2G), which is similar to results obtained from crops (Ramanjulu et al. 1994; Wang et al. 2007). An increase in GDH activity can be used to catalyze the reversible reaction of glutamate from $\mathrm{NH}_{4}{ }^{+}-\mathrm{N}$ (Skopelitis et al. 2006).

Compared with the only salinity-alkalinity stress, application of Spd significantly promoted NR, GS, GOT, GPT activities in two tomato cultivars, and inhibited GDH activity and had relatively little effect on leaf GOGAT activities in two tomato cultivars (Figure 2). Spd had more effects on nitrogen metabolism enzymes activities in 'Zhongza No. 9', except for GOT activity (Figure 2). Changes in forms of nitrogen and the particular complement of metabolic enzymes present can reflect a plant's adaptation of nitrogen metabolism to stress (Gangwar and Singh, 2011). The experiment indicates that exogenous Spd partly counteracted stressinduced increases in $\mathrm{NH}_{4}{ }^{+}-\mathrm{N}$ levels and GDH activity, as well as increased in $\mathrm{NO}_{3}{ }^{-}-\mathrm{N}$ content and the activities of NR, NiR, GS, GOGAT, and GOT in tomato seedling leaves under saline-alkaline stress. Spd may act as a kind of multi-functional signaling molecule that can activate a variety of defense reactions, resulting in maintenance of normal metabolism and enhanced resistance (Groppa and Benavides 2008). The positive effects of exogenous Spd on plant nitrogen metabolism may also include further alleviation of saline-alkaline-resulted injuries. The Spd-induced resistance to saline-alkaline stress may be associated with the conversion of Spd to putrescine or spermine. Our previous results showed that exogenous Spd promoted the conversion of free putrescine to free Spd and spermine under salinity-alkalinity stress $\mathrm{CHu}$ et al., 2012), which suggested that exogenous Spd treatment can regulate the metabolic status of polyamines caused by salinity-alkalinity stress, and eventually enhance tolerance of tomato plants to salinity-alkalinity stress. Besides, some differences in the functions of Spd among cultivars of a given species exist. However, based on our observations, exogenous Spd improves stressed plants more than a control, especially in 'Zhongza No. 9' which is a sensitivity cultivar. This result suggested that under saline-alkaline stress, the effects of exogenous Spd on nitrogen metabolism may depend on the plant species, and even cultivars.

\section{Changes in antioxidant enzymes, $\mathrm{H}_{2} \mathrm{O}_{2}, \mathrm{O}_{2}{ }^{-}$, and MDA contents in leaves}

Antioxidative enzymes like SOD, POD and CAT play a significant role in conferring tolerance of abiotic stress. In this study, saline-alkaline treatment elicited significant increases in the activities of SOD, POD, and CAT $(P<$ 0.05) and resulted in greater accumulation of $\mathrm{H}_{2} \mathrm{O}_{2}, \mathrm{O}_{2}{ }^{-}$ and MDA compared with the levels in leaves of control plants for two tomato cultivars leaves (Figure 3). This tendency is more obviously in 'Zhongza No. 9' than in 'Jingpeng Chaoguan', except for CAT activity and MDA content. Application of Spd to stressed plants significantly $(P<0.05)$ increased SOD and POD activities and decreased reactive oxygen species (ROS) and MDA contents compared to the levels in plants treated only with saline-alkaline stress (Figure 3). However, Spd had no significantly effect on CAT activity. In a word, we found that exogenous Spd efficiently alleviated saline-alkaline stress in tomato seedlings, as assessed and by enzymatic activities and ROS content. These results indicate that Spd enhances saline-alkaline tolerance in tomato seedlings by efficiently scavenging ROS.

\section{The effect of Spd on osmoregulation substance}

The accumulation of proteins in plants under saline conditions may also provide a storage form of nitrogen that is reutilized when stress is over and plays a role in osmotic adjustment. In this study, the proline and soluble sugar contents were much higher, and the soluble protein content was much lower, in leaves of two tomato cultivars subjected to saline-alkaline solution compared with the content in control plants (Figure 4) in agreement 

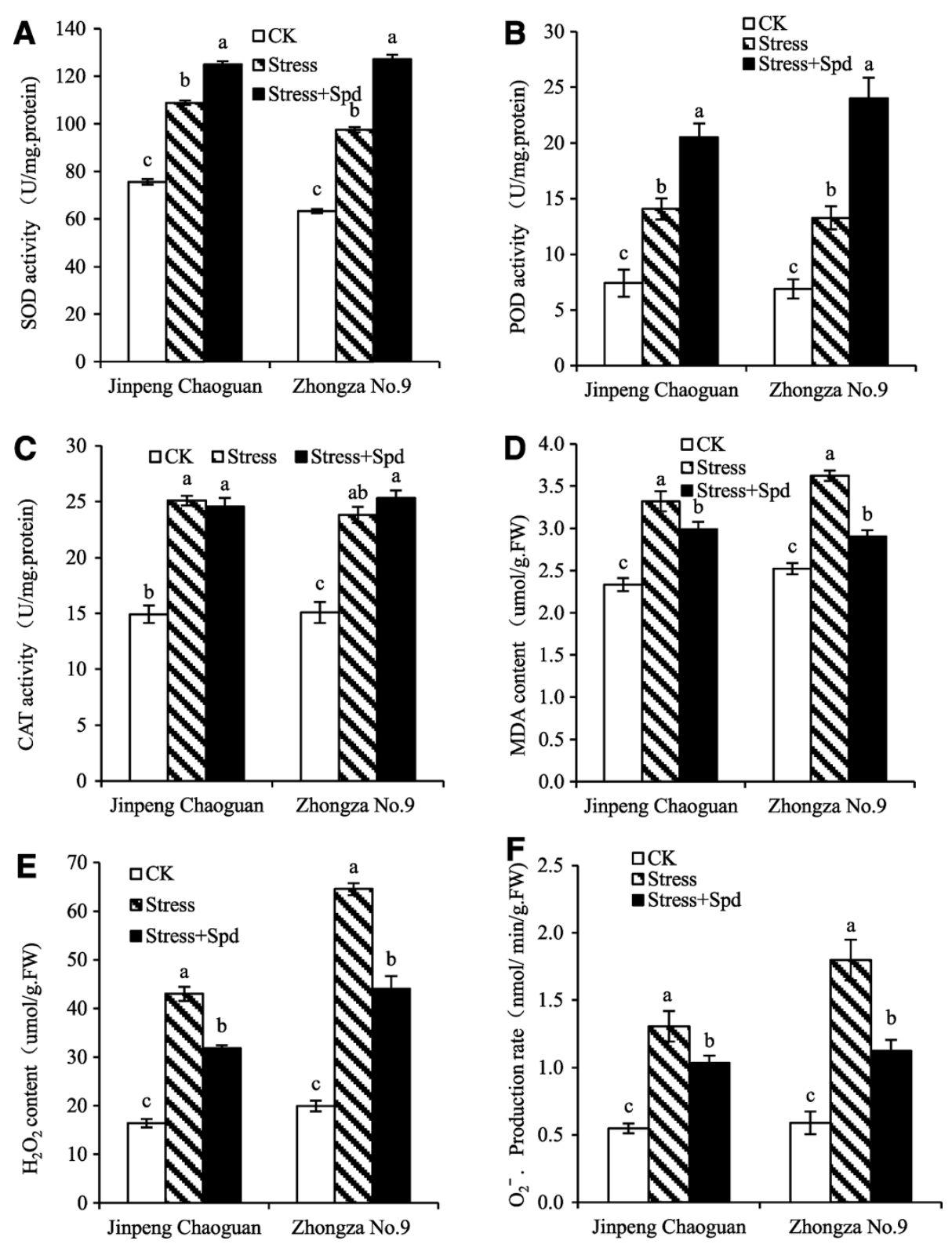

Figure 3 Effects of exogenous Spd on antioxidant enzyme activities and MDA content and ROS in leaves of tomato seedlings grown in nutrient solution or in $75 \mathrm{mM}$ saline-alkaline solution (nutrient solution with $75 \mathrm{mM}$ saline-alkaline solution; $\mathrm{NaCl}_{\mathrm{Na}} \mathrm{Na}_{4}: \mathrm{NaHCO}_{3}$ : $\left.\mathrm{Na}_{2} \mathrm{CO}_{3}=1: 9: 9: 1\right)$ with or without $0.25 \mathrm{mM}$ Spd. (A) delegated SOD activity; (B) delegated POD activity; (C) delegated CAT activity; (D) delegated MDA content; $(\mathbf{E})$ delegated $\mathrm{H}_{2} \mathrm{O}_{2}$ content; $(\mathbf{F})$ delegated $\mathbf{O}_{2}{ }^{-}$content. Bars represent the mean $\pm \mathrm{SE}(P<0.05)$ of at least three independent experiments.

with the results of Wasti et al. (2012). This may have been due to enhancement of the pathway for synthesis of proline from glutamine, or by inducing other amino acids that can be transformed to proline. Under salinity-alkalinity stress, proline not only acts as an osmolyte that can prevent cell dehydration, but is also a protective agent of many biological macromolecules and an ROS scavenger. Our finding that the leaf soluble protein level decreased in response to stress agrees with the results of Abdel-Latef
(2005), and has been suggested to be due to either the inhibition of NR activity under stress (Undovenko 1971) or to protein synthesis (Kong-Ngern et al. 2005). In this experiment, these substances increased in stressed leaves treated with Spd compared with the content in the stressonly plants (Figure 4). It has been suggested that Spd may inhibit polysaccharide hydrolyzing enzymes or accelerate the incorporation of soluble sugars into polysaccharides. Spd may act as a plant hormone or perhaps affect the 

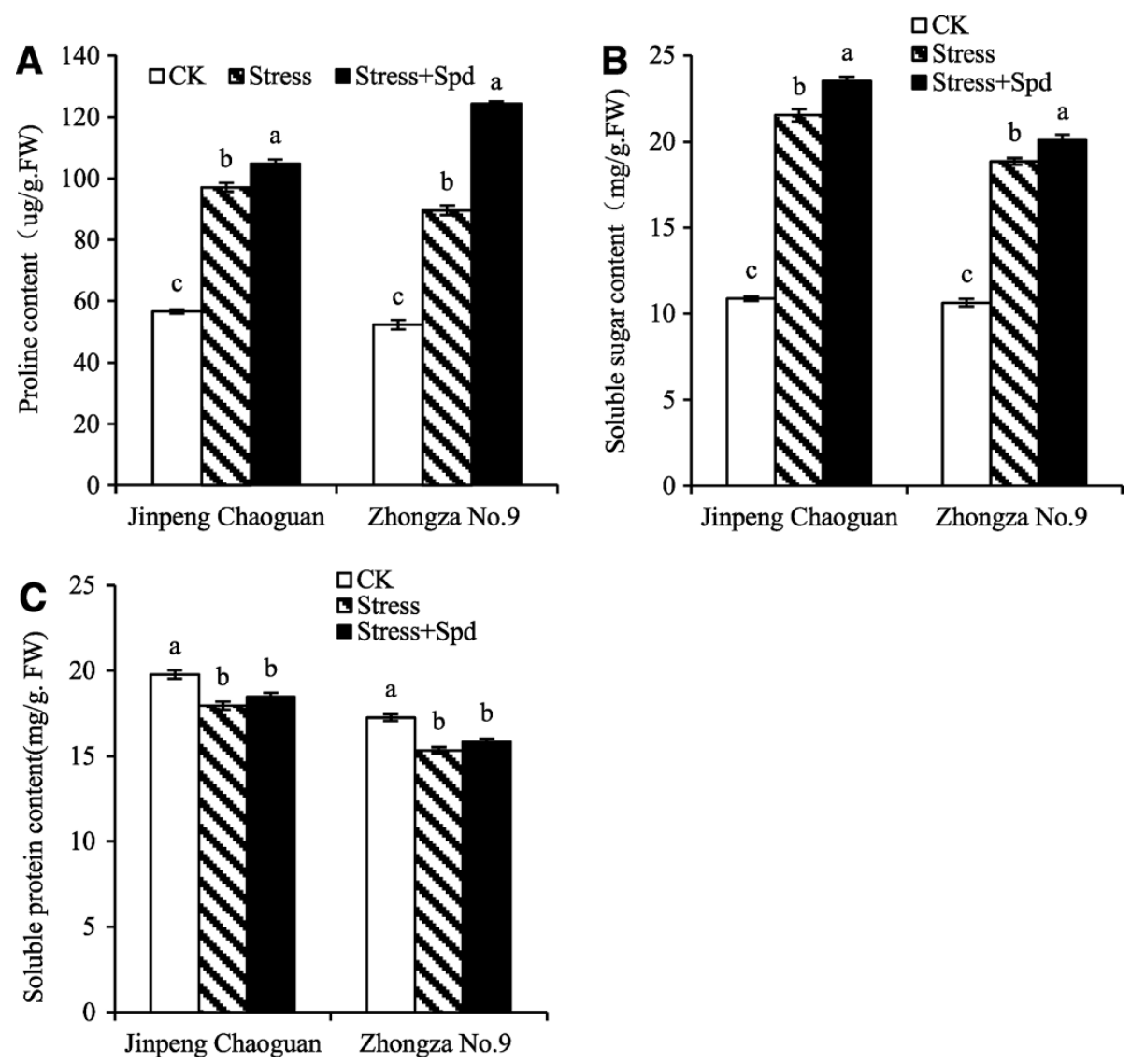

Figure 4 Effects of exogenous Spd on osmoregulatory substances in leaves of tomato seedlings under salinity-alkalinity mixed stress (nutrient solution with $75 \mathrm{mmol} / \mathrm{L}$ saline-alkaline solution; $\left.\mathrm{NaCl}: \mathrm{Na}_{2} \mathrm{SO}_{4}: \mathrm{NaHCO}_{3}: \mathrm{Na}_{2} \mathrm{CO}_{3}=1: 9: 9: 1\right)$. Bars represent the mean $\pm \mathrm{SE}(P<0.05)$ of at least three independent experiments. (A) delegated proline content; (B) delegated soluble sugar content; (C) delegated soluble protein content.

$\mathrm{Ca}^{2+}$ signaling system (Alcázar et al. 2010), participating in signal transduction under stress conditions. This effect may stimulate the synthesis and accumulation of substances that regulate osmotic adjustment in order to reduce the loss of water content of tomato seedlings and remit the damage caused by salinity-alkalinity stress.

\section{Conclusion}

In conclusion, the present results suggested that Spd positively enhanced salinity-alkalinity tolerance in tomato. Its action was associated with nitrate metabolism, antioxidant enzymes and osmoregulation. The accumulation of compatible osmolytes may compensate for the decreased water potential during salinity-alkalinity stress. Additionally, the effect of Spd was more significantly in salt-sensitive cultivar 'Zhongza No. 9'. Overall, exogenous Spd attenuated negative effects of saline-alkaline stress on plants which effects have varying effects on different tolerant tomato cultivars.

\section{Abbreviations}

CAT: Catalase; GDH: Glutamate dehydrogenase; GOGAT: Glutamine 2-oxoglutarate aminotransferase; GOT: Glutamate oxaloacetate transaminase; GPT: Glutamate pyruvate transaminase; GS: Glutamine synthetase; $\mathrm{H}_{2} \mathrm{O}_{2}$ : Hydrogen peroxide; MDA: Malondialdehyde; $\mathrm{NH}_{4}{ }^{+}$: Ammonium; $\mathrm{NH}_{4}{ }^{+}-\mathrm{N}$ : Ammonium nitrogen; NR: Nitrate Reductase; NiR: Nitrite Reductase; $\mathrm{NO}_{3}{ }^{-}$: Nitrate; $\mathrm{O}_{2}{ }^{-}$: Superoxide anion; POD: Peroxidase; ROS: Reactive oxygen species; SOD: Superoxide dismutase; Spd: Spermidine.

\section{Competing interests}

The authors declare that they have no competing interests.

\section{Authors' contributions}

$Y Z$ and $L Z$ performed these experiments. $X H$ designed the research and wrote the paper, $\mathrm{X} \mathrm{H}$ and $\mathrm{Y} Z$ analyzed data. All the authors read and approved the final manuscript.

\section{Acknowledgments}

This work was supported by grants from the National Natural Science Foundation of China (No. 31101581), National Key Technology R\&D Program in the 12th Five-year Plan of China (No. 2011BAD29B01), Scientific Research Special Fund of Northwest Agriculture \& Forestry University (QN2013018), and China Agriculture Research System (No. CARS-25-D-02). 


\section{Author details}

${ }^{1}$ College of Horticulture, Northwest Agricultural \& Forest University, Yangling 712100, China. ${ }^{2}$ College of Horticulture, Shanxi Agricultural University, Taigu 030801, China. ${ }^{3}$ Key Laboratory of Protected Horticultural Engineering in Northwest, Ministry of Agriculture, Shaanxi Yangling, 712100, China.

Received: 25 May 2014 Accepted: 21 July 2014

Published: 1 August 2014

\section{References}

Abdel-Latef AA (2005) Salt tolerance of some wheat cultivars. Ph.D. Thesis. South Valley Univ in Qena, Egypt, pp 1-159

Alcázar R, Altabella T, Marco F, Bortolotti C, Reymond M, Koncz C, Carrasco P, Tiburcio AF (2010) Polyamines: molecules with regulatory functions in plant abiotic stress tolerance. Planta 231:1237-1249. doi:10.1007/s00425.010.1130.0

Bates LS, Wadern RP, Teare ID (1973) Rapid estimation of free proline for water stress determination. Plant Soil 39:205-207. doi:10.1007/BF00018060

Bradford MM (1976) A rapid and sensitive method for the quantitation of microgram quantities of protein utilizing the principle of protein-dye binding. Anal Biochem 72:248-254. doi:10.1016/0003-2679(76) 90527-3

Cataldo DA, Haroon M, Schrader LE, Youngs VL (1975) Rapid colorimetric determination of nitrate in plant tissue by nitration of salicylic acid. Commun Soil Sci Plant 6:71-80. doi:10.1080/ 00103627509366547

Dev TB, Herbert JK (2002) $\mathrm{NH}_{4}^{+}$toxicity in higher plants: a critical review. J Plant Physiol 159:567-584. doi:10.1078/0176-1617-0774

Dhindsa RS, Plumb-dhindsa P. Thorpe TA (1981) Leaf senescence: correlated with increased levels of membrane permeability and lipid peroxidation, and decreased levels of superoxide dismutase and catalase. J Exp Bot 32:93-101. doi:10.1093/jxb/32.1.93

Frommer WB, Ludewig U, Rentsch D (1999) Taking transgenic plants with a pinch of salt. Science 285:1222-1223. doi:10.1126/science.285.5431.1222

Gajewska E, Sklodowska M (2009) Nickel-induced changes in nitrogen metabolism in wheat shoots. J. Plant Physiol 166:1034-1044. doi:10.1016/ j.jplph.2008.12.004

Gangwar S, Singh VP (2011) Indole acetic acid differently changes growth and nitrogen metabolism in Pisum sativum L. seedlings under chromium (VI) phytotoxicity: Implication of oxidative stress. Sci Hort 129:321-328. doi:10.1016/j.scienta.2011.03.026

Groppa MD, Benavides MP (2008) Polyamines and abiotic stress: recent advances. Amino Acids 34:35-45. doi:10.1007/s00726-007-0501-8

Hu XH, Zhang Y, Shi Y, Zhang Z, Zou ZR, Zhang H, Zhao JZ (2012) Effect of exogenous spermidine on polyamine content and metabolism in tomato exposed to salinity-alkalinity mixed stress. Plant Physiol Biochem 57:200-209. doi:10.1016/j.plaphy.2012.05.015

Huang CJ, Zhao SY, Wang LC, Anjum SA, Chen M, Zhou HF, Zou CM (2013) Alteration in chlorophyll fluorescence, lipid peroxidation and antioxidant enzymes activities in hybrid ramie (Boehmeria nivea L.) under drought stress. Aust J Crop Sci 7:594-599

Kochba J, Lavee S, Spiegel-Roy P (1977) Differences in peroxidase activity and isoenzymes in embryogenic and non-embryogenic 'Shamouti' orange ovular callus lines. Plant Cell Physiol 18:463-467

Kong-Ngern K, Daduang S, Wongkham CH, Bunnag S, Kosittrakuna M, Theerakulpisuta P (2005) Protein profiles in response to salt stress in leaf sheaths of rice seedlings. Sci Asia 31:403-408. doi:10.2306/ scienceasia15131874.2005.31.403

Krom MD (1980) Spectrophotometric determination of ammonia: a study of a modified Berthelot reaction using salicylate and dichloroisocyanurate. Analyst 105:305-316. doi:10.1039/AN9800500305

Liang CG, Chen LP, Wang Y, Liu J, Xu GL, Li T (2011) High temperature at grainfilling stage affects nitrogen metabolism enzyme activities in grains and grain nutritional quality in rice. Rice Sci 18:210-216. doi:10.1016/S16726308(11)60029

Lillo C (1984) Diurnal variations of nitrite reductase, glutamine synthetase, glutamate synthase, alanine aminotransferase and aspartate aminotransferase in barley leaves. Physiol Plant 61:214-218. doi:10.1111/j.1399-3054.1984. tb05899.x

Masclaux-Daubresse C, Reisdorf-Cren M, Pageau K, Lelandias M, Grandjean J, Valadier MH, Feraud M, Jouglet T, Suzuki A (2006) Glutamine synthetaseglutamate synthase pathway and glutamate dehydrogenase play distinct roles in the sink source nitrogen cycle in tobacco. Plant Physiol 140:444-456. doi:10.1104/pp.105.071910
Orozco-Cardenas ML, Narvaez-Vasquez J, Ryan CA (2001) Hydrogen peroxide acts as a second messenger for induction of defense genes in tomato plants in response to wounding, systemin, and methyl jasmonate. Plant Cell 13:179-191. doi:10.1105/tpc.13.1.179

Ramanjulu S, Veeranjaneyulu K, Sudhakar C (1994) Short-term shifts in nitrogen metabolism in mulberry (Morus alba L.) under salt shock. Phytochem 37:991-995. doi:10.1016/S0031-9422(00)89515-1

Rhodes D, Verslues PE, Sharp RE (1999) Role of amino acids in abiotic stress resistance. In: Singh BK (ed) Plant Amino Acids: Biochemistry and Biotechnology. Dekker, New York, pp 319-356

Roychoudhury A, Basu S, Sengupta DN (2011) Amelioration of salinity stress by exogenously applied spermidine or spermine in three varieties of indica rice differing in their level of salt tolerance. J Plant Physiol 168:317-328. doi:10.1016/j.jplph.2010.07.009

Shahba Z, Baghizadeh A, Vakili SMA, Yazdanpanah A, Yosefi M (2010) The salicylic acid effect on the tomato (Lycopersicum esculentum Mill.) sugar, protein, and proline contents under salinity stress $(\mathrm{NaCl})$. J Biophys Struct Biol 2:35-41

Shehab GG, Ahmed OK, El-beltagi HS (2010) Effects of various chemical agents for alleviation of drought stress in rice plants (Oryza sativa L.). Not Bot Hort Agrobot Cluj 38:139-148

Shi DC, Sheng YM (2005) Effect of various salt-alkaline mixed stresses conditions on sunflower seedlings and analysis of their stress factors. Environ Exp Bot 54:8-21. doi:10.1016/j.envexpbot.2004.05.003

Skopelitis DS, Paranychianakis NV, Paschalidis KA (2006) Abiotic stress generates ROS that signal expression of anionic glutamate dehydrogenases to form glutamate for proline synthesis in tobacco and grapevine. Plant Cell 18:2767-2781. doi:10.1105/tpc.105.038323

Undovenko GV (1971) Effect of salinity of substrateon nitrogen metabolism of plants with different salt tolerance. Agrokhimiya 3:23-31

Wang ZQ, Yuan YZ, Ou JQ, Lin QH, Zhang CF (2007) Glutamine synthetase and glutamate dehydrogenase contribute differentially to proline accumulation in leaves of wheat (Triticum aestivum) seedlings exposed to different salinity. J Plant Physiol 164:695-701. doi:10.1016/j.jplph.2006.05.001

Wasti S, Mimouni H, Smiti S, Zid E, Ahmed HB (2012) Enhanced salt tolerance of tomatoes by exogenous salicylic acid applied through rooting medium. J Integrative Bio 16:200-207. doi:10.1089/omi.2011.0071

Xu PL, Guo YK, Bai JG, Shang L, Wang XJ (2008) Effects of long-term chilling on ultrastructure and antioxidant activity in leaves of two cucumber cultivars under low light. Physiol Plant 132:467-478. doi:10.1111/j.13993054.2007.01036.x

Yang CW, Chong JN, Kim CM, Li CY, Shi DC, Wang DL (2007) Osmotic adjustment and ion balance traits of an alkali resistant halophyte Kochia sieversiana during adaptation to salt and alkali conditions. Plant Soil 294:263-276. doi:10.1007/s11104-007-9251-3

Yemm EW, Willis AJ (1954) The estimation of carbohydrates in plant extracts by anthrone. Biochem J 57:508-514

doi:10.1186/s40529-014-0058-2

Cite this article as: Zhang et al:: Exogenous spermidine-induced changes at physiological and biochemical parameters levels in tomato seedling grown in saline-alkaline condition. Botanical Studies 2014 55:58.

\section{Submit your manuscript to a SpringerOpen ${ }^{\odot}$ journal and benefit from:}

- Convenient online submission

$\checkmark$ Rigorous peer review

- Immediate publication on acceptance

- Open access: articles freely available online

- High visibility within the field

- Retaining the copyright to your article

Submit your next manuscript at springeropen.com 